Newfoundland and Labrador Studies

\title{
Catherine Bush. Blaze Island
}

\section{Olivia Robinson}

Volume 35, Number 1-2, 2020

URI: https://id.erudit.org/iderudit/1076772ar

DOI: https://doi.org/10.7202/1076772ar

See table of contents

Publisher(s)

Faculty of Arts, Memorial University

ISSN

1719-1726 (print)

1715-1430 (digital)

Explore this journal

Cite this review

Robinson, O. (2020). Review of [Catherine Bush. Blaze Island]. Newfoundland and Labrador Studies, 35(1-2), 147-148. https://doi.org/10.7202/1076772ar viewed online.

https://apropos.erudit.org/en/users/policy-on-use/ 
Catherine Bush. Blaze Island. Fredericton, NB: Goose Lane Editions, 2020. ISBN 978-1-773-10105-7

Climate crisis fiction meets The Tempest in this novel, set on the fictional island of Blaze. The island is heavily inspired by Fogo Island (as the map at the front shows), but all the communities and coves have been creatively renamed by Bush. We follow the story of Miranda and her father as they try to live in a more sustainable way. They own a small house overlooking the sea and spend their time gardening and monitoring the weather. But their calm, quiet way of life is becoming more unstable due to the increasing severity and frequency of catastrophic storms.

As someone lucky enough to have spent two summers on Fogo Island, I enjoyed revisiting the place through Blaze Island. I loved how Bush wrote about the women who run the stores in each community and her descriptions of the beautiful, barren landscape. A few Fogo Island residents are also recognizable (albeit with slightly altered names), and this added to the overall reading experience for me. Catherine Bush also spent a lot of time on Fogo Island and it is evident how much research went into the writing of Blaze Island.

When the novel begins, a category 5 hurricane is battering the island, confirming all of Miranda's father's fears. Much like the storm at the beginning of The Tempest, this hurricane is a forewarning. And also much like a storm, Bush does not ease readers into the story. The first scene is full of action and tension as a man is almost swept away by a road washout but manages to cling to the railing outside Miranda's house. Although skeptical of outsiders, Miranda's father rescues Frank, who has travelled to Blaze from the United States in search of exotic birds that get thrown off course by strong winds. However, as the novel progresses, it becomes clear Frank may not be telling the whole truth.

Their life on the island is an attempt at a fresh start. Miranda's mother, Jenny, died a short time before Miranda and her father moved to Blaze. Being only 10 years old at the time, Miranda adapted easily 
to their new way of life. Their house is a good distance away from the other homes in the community of Pummelly, based on the Irish community of Tilting on Fogo Island. In his attempts to conserve gasoline and limit their interaction with the outside world, Miranda's father doesn't allow her to travel to the mainland. Much like Shakespeare's Prospero, Miranda's father tries to protect his daughter by keeping her close. She rarely leaves the safety of Pummelly.

Blaze Island is a perfect combination of a character-driven narrative and a strong underlying plot. The clever nods to The Tempest are well executed and the discussions about the climate crisis are accessible and well written. All of the characters are compelling and complex. With storms and severe weather becoming increasingly common, the tension is always there as the waves pound against the rocks.

One example of this sense of lurking tension is embodied in the character of Caleb, who used to be Miranda's closest friend. Caleb works for Miranda's father, who in his past life as a university professor in Princeton, New Jersey, studied the climate. When he and Miranda moved to Blaze, he promised he wouldn't do any of that work anymore. But once a scientist, always a scientist, and he soon built a weather monitoring station in a cabin in the woods. Unlike most of his friends, Caleb does not want to leave the island now that he is grown up. He wants to make a home there and has his sights set on the house across the cove from Miranda. The dissolution of Caleb and Miranda's friendship is hinted at throughout the novel and builds to a dramatic realization.

The novel is like the piece of iceberg ice Miranda places on her tongue; it fizzles and pops, releasing bubbles of information slowly over time. There's something lurking, a sense of uneasiness that permeates the lives of these characters who are trying to make the most of their time on the little island in the middle of the Atlantic.

Olivia Robinson Memorial University 